\title{
Activity of Aniline Methylation over Fe-Cu-Cr Ternary Spinel Systems
}

\author{
Reni George, Kochurani George, Sankaran Sugunan* \\ Department of Applied Chemistry, Cochin University of Science and Technology, Kochi-682022, \\ Kerala, India
}

Received: 18th July 2013; Revised: 5th November 2013; Accepted: 1st December 2013

\begin{abstract}
A series of spinels having the general formula $\mathrm{CuCr}_{2-\mathrm{x}} \mathrm{Fe}_{\mathrm{x}} \mathrm{O}_{4}$ with $\mathrm{x}=0.25,0.75,1.25$, 1.75 were prepared by co-precipitation method. The catalysts were characterized by various physico-chemical methods like XRD, BET, SEM, EDX and TPD. The reaction of aniline with methanol was studied in a fixedbed reactor system as a potential source for the production of various methyl anilines. It was observed that systems possessing low ' $x$ ' values are highly selective and active for N-monoalkylation of aniline leading to $\mathrm{N}$-methylaniline. Reaction parameters were properly varied to optimize the reaction conditions for obtaining $\mathrm{N}$-methylaniline selectively and in better yield. Among the systems $\mathrm{CuCr}_{1.75} \mathrm{Fe}_{0.25} \mathrm{O}_{4}$ is remarkable due to its very high activity and excellent stability. Under the optimized conditions $\mathrm{N}$ methylaniline selectivity exceeded $91 \%$. $\mathrm{CuCr}_{1.25} \mathrm{Fe}_{0.75} \mathrm{O}_{4}$ gives better conversion than $\mathrm{CuCr}_{1.75} \mathrm{Fe}_{0.25} \mathrm{O}_{4}$ in $\mathrm{CuCr}_{2-\mathrm{x}} \mathrm{Fe}_{\mathrm{x}} \mathrm{O}_{4}$ series. The Lewis acid sites of the catalysts are mainly responsible for the good catalytic performance. (C) 2014 BCREC UNDIP. All rights reserved
\end{abstract}

Keywords: aniline methylation; spinels system; Fe-Cu-Cr; co-precipitation; alkylation

How to Cite: George, R., George, K., Sugunan, S. (2014). Activity of Aniline Methylation over Fe-CuCr Ternary Spinel Systems. Bulletin of Chemical Reaction Engineering \& Catalysis, 9 (1): 39-44.

(doi:10.9767/bcrec.9.1.5169.39-44)

Permalink/DOI: http://dx.doi.org/10.9767/bcrec.9.1.5169.39-44

\section{Introduction}

Metal oxides having the spinel structure show greater structural stability and catalytic activity. Spinels have different applications in the area of heterogeneous catalysts. Spinels are a class of ternary oxides with composition $\mathrm{AB}_{2} \mathrm{O}_{4}$ where $\mathrm{A}$ and $\mathrm{B}$ are divalent and trivalent cations respectively; A ions occupy tetrahedral sites and B ions occupy octahedral sites [1-2]. The crystallographic structure of a spinel is

* Corresponding Author.

E-mail: ssg@cusat.ac.in (S. Sugunan), renigeorge@cusat.ac.in (R. George)

Tel: + 91-484-2575804. Fax: +91-484-2577595 packed face centered cubic close packed array of anions with holes partly filled by the cations. In a normal spinel structure the entire $\mathrm{A}$ atoms are tetrahedrally coordinated while B atoms are octahedrally surrounded by oxygen atoms. Chromite spinels have general formula $\mathrm{MCr}_{2} \mathrm{O}_{4}$; where $\mathrm{M}$ is a bivalent metal ion. All $\mathrm{MCr}_{2} \mathrm{O}_{4}$ chromites have normal spinel structure with $\mathrm{M}$ in tetrahedral sites because of strong preference of $\mathrm{Cr}^{3+}$ ions for octahedral sites [3]. This was confirmed by thermodynamic and quantum chemical calculations [4, 5].

Metal chromites have been extensively used as catalyst in dehydrogenation [6-8], oxidation of hydrocarbon and dehydration of alcohols $[9,10]$. Mixed oxides of chromium posses p-type 
semi conductivity $[11,12]$. The catalytic activity increases with increasing p-type conductivity. Metal oxides with high conductivity have high activity regardless of their nature [13]. p-type semiconductors that can be converted to n-type are effective catalysts [14].

$\mathrm{CuCr}_{2} \mathrm{O}_{4}$ is a normal spinel oxide with $\mathrm{Cu}$ as divalent ion and $\mathrm{Cr}$ as trivalent ion. Metal chromites have been extensively used as catalyst in dehydrogenation, oxidation of hydrocarbon and dehydration of alcohols. $\mathrm{CuCr}_{2} \mathrm{O}_{4}$ is a normal spinel and $\mathrm{CuFe}_{2} \mathrm{O}_{4}$ is a tetragonal spinel. Alkylation of aniline is an industrially outstanding reaction due to the numerous uses of alkylated products. Aniline methylation is a pseudo first order reaction with respect to aniline concentration N-methylation products (NMA and NNMA) are predominant in the temperature range 573-673 K. Selectivity to N, N dimethyl aniline is enhanced as reaction temperature and contact time increases. Schematic representation is given in Figure 1.

An-Nan Ko et al. [15] investigated the aniline methylation over g-alumina, which produced successively NMA and NNDMA. Narayanan et.al investigated the aniline methylation using transition metal oxides. Supported oxides are also used as catalyst for this type of reaction [16].

According to Elangovan et al. [17], weak and moderate acid sites are sufficient for Nalkylation where as strong acid sites are mandatory for C-alkylation. Aniline alkylation takes place on acidic [18] and on basic zeolites [19]. The reaction performed on zeolites with redox properties. Vapour phase alkylation of aniline over zeolites and aluminophosphate depends on acid-base properties and shape selectivity [20]. Selective N, N methylation over zeolites was reported. Mixture of N- and C-alkylated products can be obtained over more acidic form of the zeolite. Elangovan et al. also studied alkylation of aniline with methanol over various aluminophosphates in the vapour phase [17]. The products formed were NMA, NNDMA, and NMT. Acidity of the catalyst plays an important role in the methylation of aniline. Vanadium incorporated aluminophosphate molecular sieves leads to the formation of NMA and NNDMA [17]. High selectivity to NMA is obtained over metallosilicates. Bautista et al. reported such reactions using $\mathrm{CrPO}_{4}$ as catalyst [21].

Sugunan et al. calculated the kinetic parameters such as the activation energy and Arrhenius frequency factor for the $\mathrm{N}$-methylation of aniline using methanol over Co ferrites [22, 23]. For these systems, maximum conversion obtained is $79.60 \%$ and NMA selectivity is $71.40 \%$ and suggests that surface basicity plays a dominating role in aniline methylation. Acidity and aniline alkylation activity of mixed Fe-Al pillared montmorillonites has been studied by sugunan et al. and suggest that weak and moderate acid sites influence the catalytic activity [24]. The catalytic activity of $\mathrm{Cr}-\mathrm{Mn}$ ferrospinels
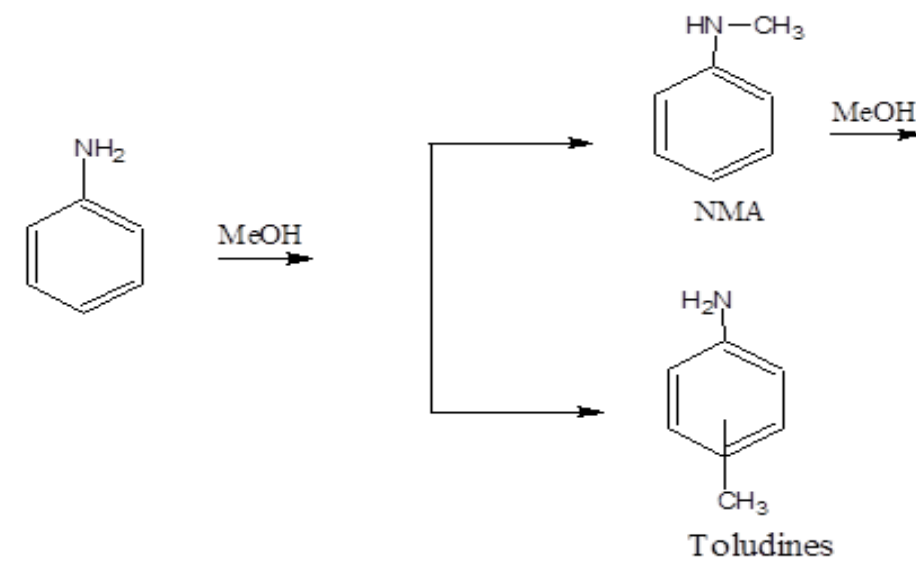

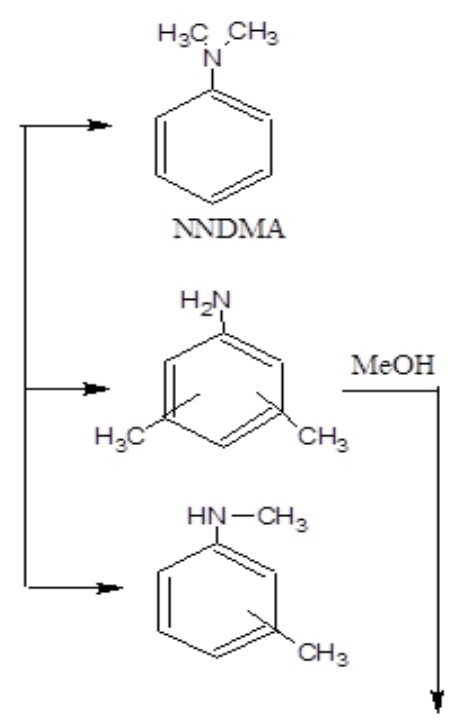

Product like

N-methyl xylidines

\& N,N-dimethyl toludines

Figure 1. Scheme for aniline methylation 
in selective alkylation of aniline and related to their acid-base properties and also the cation distribution were reported [25]. The vapourphase methylation of aniline by methanol has been extensively studied because its products are very essential intermediates in textile dye, perfumes, paper industry.

In present work spinels prepared via coprecipitation method have excellent conversion for aniline methylation due to their surface properties. In the present systems CFC 2 shows maximum conversion of $59.32 \%$ and $87.68 \%$ selectivity towards NMA. In our systems, the entire catalysts show good yield for NMA. It is observed that weak acid sites on the catalyst surface are favourable for the $\mathrm{N}$-alkylation of aniline.

\section{Materials and Methods}

\subsection{Materials}

Aniline (99\% Merck), Methanol (99\% Merck), $\quad \mathrm{Cu}\left(\mathrm{NO}_{3}\right)_{2} .3 \mathrm{H}_{2} \mathrm{O} \quad(99.5 \%)$, $\mathrm{Fe}\left(\mathrm{NO}_{3}\right)_{3} .9 \mathrm{H}_{2} \mathrm{O}, \quad \mathrm{Cr}\left(\mathrm{NO}_{3}\right)_{3} .9 \mathrm{H}_{2} \mathrm{O}$ (Loba chemicals 98\%), $\mathrm{NaOH}$ (Rankem 98\%). All chemicals used were of the highest purity.

\subsection{Synthesis of chromite spinels}

Solutions of metal nitrates are required for the preparation. Stoichiometric masses of the metal nitrates were accurately weighed out and dissolved in distilled water to get $10 \%$ solutions. To the metal nitrate solution, $10 \% \mathrm{NaOH}$ solutions are added drop-by-drop and stirred well by using a mechanical stirrer. $\mathrm{pH}$ was adjusted between 9 and 10. The precipitation is carried out at a temperature of $80^{\circ} \mathrm{C}$.The precipitate was kept overnight for ageing and then washed several times with distilled water until free from nitrate ions and alkali. It was filtered, dried in an oven at $80^{\circ} \mathrm{C}$ for $24 \mathrm{~h}$ and the dried materials were powdered and sieved below $75 \mu \mathrm{m}$ mesh. The powdered samples were calcined at $500{ }^{\circ} \mathrm{C}$ for $6 \mathrm{~h}$ to achieve complete

Table 1. Catalyst notation

\begin{tabular}{ccc}
\hline $\mathrm{x}$ & $\begin{array}{c}\text { Catalyst Composition } \\
\left(\mathrm{CuCr}_{2-\mathrm{x}} \mathrm{Fe}_{\mathrm{x}} \mathrm{O}_{4} \text { series }\right)\end{array}$ & $\begin{array}{c}\text { Catalyst } \\
\text { Labeling }\end{array}$ \\
\hline 0 & $\mathrm{CuCr}_{2} \mathrm{O}_{4}$ & $\mathrm{CC}$ \\
0.25 & $\mathrm{CuCr}_{1.75} \mathrm{Fe}_{0.25} \mathrm{O}_{4}$ & $\mathrm{CFC} 1$ \\
0.75 & $\mathrm{CuCr}_{1.25} \mathrm{Fe}_{0.75} \mathrm{O}_{4}$ & $\mathrm{CFC} 2$ \\
1.25 & $\mathrm{CuCr}_{0.75} \mathrm{Fe}_{1.25} \mathrm{O}_{4}$ & $\mathrm{CFC} 3$ \\
1.75 & $\mathrm{CuCr}_{0.25} \mathrm{Fe}_{1.75} \mathrm{O}_{4}$ & $\mathrm{CFC} 4$ \\
2 & $\mathrm{CuFe}_{2} \mathrm{O}_{4}$ & $\mathrm{CF}$ \\
\hline
\end{tabular}

spinel phase formation. Synthesized samples are summarized in Table 1.

\subsection{Characterization of synthesized mate- rials}

All the prepared catalysts were characterized by different physico-chemical techniques viz X-ray Diffraction (XRD), Energy Dispersive X-ray Fluorescence Analysis (EDX), Scanning Electron Microscopy (SEM), Surface area measurements (BET) and acidity measurement by Temperature programmed desorption of ammonia. Micromeritics Gemini surface area analyzer was used to determine the surface area with nitrogen as adsorbate. EDX spectra of the samples were recorded in an EDX-JEM-35 instrument (JEOL co-link system AN-1000 Si detector). The XRD pattern of catalyst was taken by using Philips diffractometer (PW 1710). To determine the acidity of the catalysts, ammonia TPD measurements in the range $100-600{ }^{\circ} \mathrm{C}$ were performed in a conventional flow-type apparatus at a heating rate of $20{ }^{\circ} \mathrm{C} \mathrm{min}-1$ and in a nitrogen atmosphere.

\subsection{Aniline Methylation}

Aniline methylation was carried out in a self assembled fixed bed flow reactor made up of a glass tube at atmospheric pressure. $0.5 \mathrm{~g}$ of the catalyst was kept at the centre of the reactor which is packed with glass wool. The reactor was heated with help of a furnace. A solution of aniline in methanol was introduced to the reactor using a syringe pump at the required flow rate and reaction temperature. Analysis of products was done by Gas chromatograph (Chemito GC 1000, flame ionization detector) equipped with a SE-30 capillary column.

\section{Results and Discussion}

\subsection{X-Ray Diffraction (XRD) Analysis}

A sharp peak observed at $35^{\circ}$ is due to the spinel phase formed. By the addition of iron, lattice parameter decreases. This is due to the addition of $\mathrm{Fe}^{3+}$ ions into octahedral sites. The XRD peak for substituted $\mathrm{Cu}-\mathrm{Cr}$ spinels shows the presence of spinel phase formation. It can be observed that, spinel phase was formed at $500{ }^{\circ} \mathrm{C}$ hence it was taken as optimum calcination temperature for the prepared chromites. Table 2 shows XRD data for $\mathrm{CuCr}_{2-\mathrm{x}} \mathrm{Fe}_{\mathrm{x}} \mathrm{O}_{4}$ series. Figure 2 represents the $\mathrm{X}$-ray diffractogram of $\mathrm{CuCr}_{2-\mathrm{x}} \mathrm{Fe}_{\mathrm{x}} \mathrm{O}_{4}$ series. The results confirm the crystal structure of the systems. CF has lowest crystallite size and CFC 4 has highest crystallite size in the $\mathrm{CuCr}_{2-\mathrm{x}} \mathrm{Fe}_{\mathrm{x}} \mathrm{O}_{4}$ series. 
Crystallite size is calculated by Scherrer equation.

\subsection{Energy Dispersive X-ray fluorescence (EDX) analysis}

The elemental composition of chromite spinels determined by EDX analysis is given in Table 3. It is seen that the theoretical values are in accordance with the experimental value is almost all cases. The difference in values is due to leaching of metal in contact with mother liquor and also due to experimental error.

\subsection{Scanning Electron Microscopy (SEM)}

Scanning electron micrographs of some representative systems are given below. SEM analysis gives us an idea about the surface topography of the catalyst. Figure 3 represents the micrographs of CC, CFC 2 and CF. The particle size is observed to be larger in the case of CFC 2. Aggregate nature was observed for all samples.

Table 2. XRD data for $\mathrm{CuCr}_{2-\mathrm{x}} \mathrm{Fe}_{\mathrm{x}} \mathrm{O}_{4}$ series

\begin{tabular}{ccccc}
\hline $\begin{array}{c}\text { Cata- } \\
\text { lyst }\end{array}$ & $\begin{array}{c}\mathrm{d}_{\mathrm{hkl}} \\
(\mathrm{d}-\mathrm{spacing}) \\
\mathrm{A}^{\circ}\end{array}$ & $\begin{array}{c}\text { Lattice } \\
\text { para- } \\
\text { meter } \\
(\mathrm{nm})\end{array}$ & $\begin{array}{c}\text { Unit cell } \\
\text { volume } \\
\left(\mathrm{nm}^{3}\right)\end{array}$ & $\begin{array}{c}\text { Crys- } \\
\text { tal } \\
\text { size } \\
(\mathrm{nm})\end{array}$ \\
\hline $\mathrm{CC}$ & 2.55394 & 4.4234 & 86.5503 & 10.61 \\
$\mathrm{CFC} 1$ & 2.55251 & 4.4036 & 85.3933 & 9.093 \\
$\mathrm{CFC} 2$ & 2.51519 & 4.3563 & 82.6710 & 17.40 \\
$\mathrm{CFC} 3$ & 2.51633 & 4.3583 & 82.7849 & $\begin{array}{c}18.25 \\
\text { CFC4 }\end{array}$ \\
$\mathrm{CF}$ & 2.51828 & 4.3617 & 82.9788 & 21.70 \\
$\mathrm{C}$ & 2.50666 & 4.3415 & 81.8313 & 8.17 \\
\hline
\end{tabular}

\subsection{BET Surface area and pore volume measurements}

The surface area data is shown in the Table 4. Surface area and pore volume increases as the amount of $\mathrm{Fe}$ content increases but after CFC3 both are decreases. It is observed that CFC3 is having the highest surface area among the Fe-chromite spinels.

\subsection{Surface Acidity measurements by TPD $-\mathrm{NH}_{3}$}

The TPD of ammonia was used to characterize the acid site distribution and furthermore to obtain the quantitative amount of acid site in the specified temperature range. Ammonia is an excellent probe molecule as it allows the determination of both the protonic and cationic acid centers. In this method, the interaction of acid sites and basic probe molecule (ammonia) is studied to determine the amount and strength of acid sites. The acid site distribution pattern can be classified into weak (desorption at $100-200{ }^{\circ} \mathrm{C}$ ), medium $\left(201-400{ }^{\circ} \mathrm{C}\right)$ and strong $\left(401-600{ }^{\circ} \mathrm{C}\right.$ ) acid sites. The amount of ammonia desorbed at $100^{\circ} \mathrm{C}$ may contain some

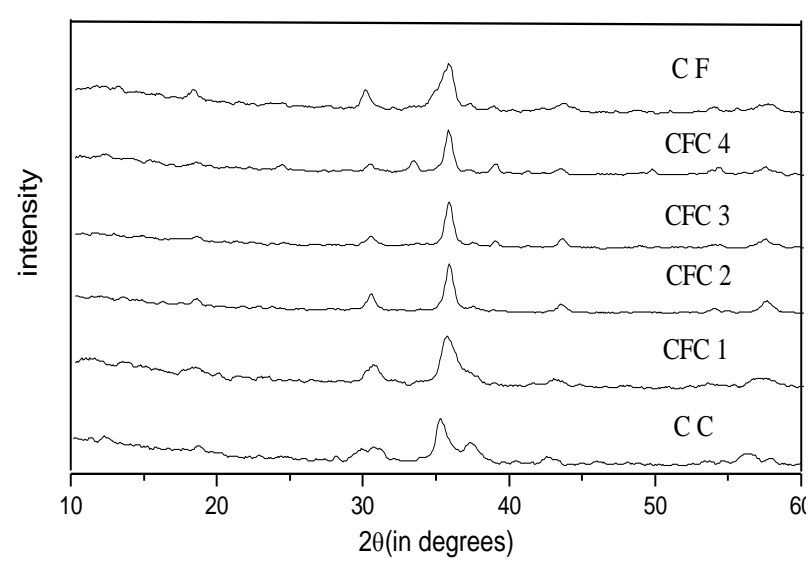

Figure 2. XRD profiles for $\mathrm{CuCr}_{2-\mathrm{x}} \mathrm{Fe}_{\mathrm{x}} \mathrm{O}_{4}$ series

Table 3. EDX data for chromite spinels

\begin{tabular}{|c|c|c|c|c|c|c|}
\hline \multirow{3}{*}{ Catalyst } & \multicolumn{6}{|c|}{ Atomic (\%) } \\
\hline & \multicolumn{3}{|c|}{ Experimental } & \multicolumn{3}{|c|}{ Theoretical } \\
\hline & $\mathrm{Cu}$ & $\mathrm{Fe}$ & $\mathrm{Cr}$ & $\mathrm{Cu}$ & $\mathrm{Fe}$ & $\mathrm{Cr}$ \\
\hline $\mathrm{CC}$ & 36.94 & - & 63.06 & 33.33 & - & 66.67 \\
\hline CFC 2 & 37.34 & 22.64 & 40.02 & 33.33 & 25.0 & 41.67 \\
\hline $\mathrm{CF}$ & 32.75 & 67.25 & - & 33.33 & 66.67 & - \\
\hline
\end{tabular}



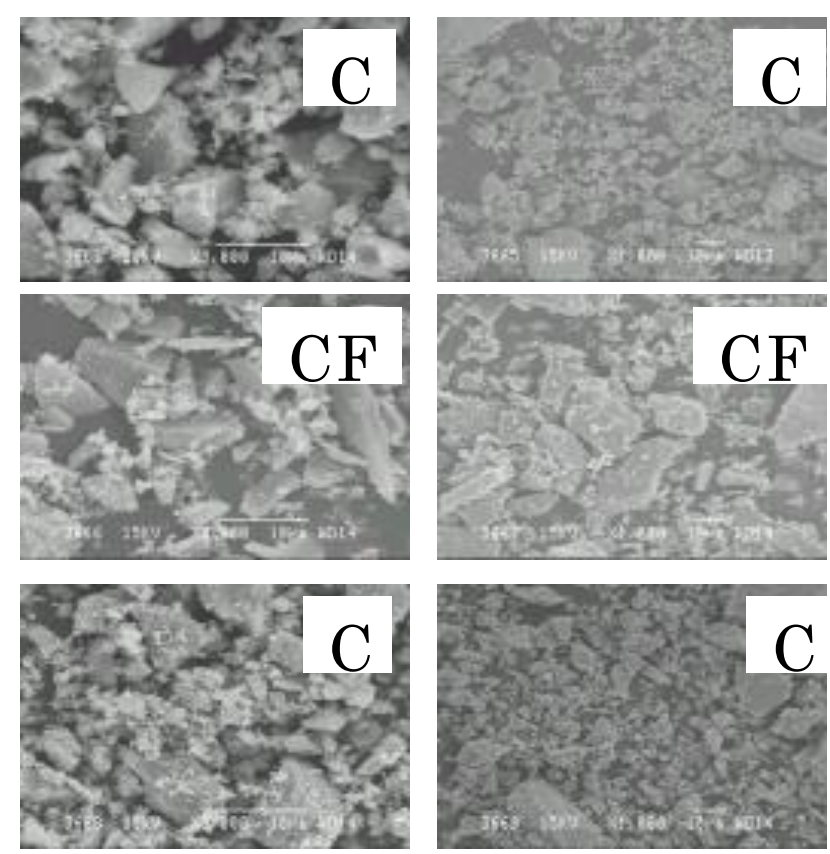

Figure 3. Scanning Electron Micrographs

Table 4. Surface areas and total pore volume of different chromite spinels

\begin{tabular}{|c|c|c|c|}
\hline \multirow{2}{*}{ Catalyst } & \multicolumn{2}{|c|}{ Surface Area $\left(\mathrm{m}^{2} / \mathrm{g}\right)$} & \multirow{2}{*}{$\begin{array}{l}\text { Pore Vol- } \\
\text { ume } \\
\left(\mathrm{cm}^{3} / \mathrm{g}\right)\end{array}$} \\
\hline & BET & Langmuir & \\
\hline $\mathrm{CC}$ & 26.76 & 39.22 & 0.09 \\
\hline $\mathrm{CFC} 1$ & 25.91 & 37.89 & 0.10 \\
\hline $\mathrm{CFC} 2$ & 35.48 & 51.76 & 0.11 \\
\hline CFC3 & 39.3 & 57.4 & 0.05 \\
\hline $\mathrm{CFC} 4$ & 27.5 & 40.1 & 0.03 \\
\hline $\mathrm{CF}$ & 23.7 & 34.6 & 0.03 \\
\hline
\end{tabular}

amount of physisorbed ammonia too. Table 5 shows acidity values of $\mathrm{CuCr}_{2-\mathrm{x}} \mathrm{Fe}_{\mathrm{x}} \mathrm{O}_{4}$ series. It is observed that CFC 2 has higher acidity in $\mathrm{CuCr}_{2-\mathrm{x}} \mathrm{Fe}_{\mathrm{x}} \mathrm{O}_{4}$ series.

\subsection{Activity of different catalytic systems}

A comparison of the catalytic activity of various chromite spinel catalysts in vapour phase aniline conversion is discussed in the following section. All the reactions are carried out at a temperature of $300^{\circ} \mathrm{C}$ for $2 \mathrm{~h}$ that a flow rate of $4 \mathrm{ml} / \mathrm{h}$. The results are given in the Table 6 . The result shows that $\mathrm{CFC} 2$ has high aniline conversion in $\mathrm{CuCr}_{2-\mathrm{x}} \mathrm{Fe}_{\mathrm{x}} \mathrm{O}_{4}$ series. Acidity and surface area has directly influences aniline methylation. From Table 4 and Table 5 it is
Table 5. Acidity values of $\mathrm{CuCr}_{2-\mathrm{x}} \mathrm{Fe}_{\mathrm{x}} \mathrm{O}_{4}$ series

\begin{tabular}{ccccc}
\hline & \multicolumn{4}{c}{$\mathrm{NH}_{3}$ desorbed $\left(\mathrm{mmol.g}^{-1}\right)$} \\
\cline { 2 - 5 } Catalyst & $\begin{array}{c}\text { Weak } \\
100-200 \\
{ }^{\circ} \mathrm{C}\end{array}$ & $\begin{array}{c}\text { Medium } \\
201-400 \\
{ }^{\circ} \mathrm{C}\end{array}$ & $\begin{array}{c}\text { Strong } \\
401-600 \\
{ }^{\circ} \mathrm{C}\end{array}$ & $\begin{array}{c}\text { Total } \\
100- \\
600{ }^{\circ} \mathrm{C}\end{array}$ \\
\hline $\mathrm{CC}$ & 0.12 & 0.13 & 0.02 & 0.27 \\
$\mathrm{CFC} 1$ & 0.13 & 0.09 & 0.05 & 0.28 \\
$\mathrm{CFC} 2$ & 0.26 & 0.19 & 0.02 & 0.41 \\
$\mathrm{CFC} 3$ & 0.22 & 0.054 & 0.01 & 0.28 \\
$\mathrm{CFC} 4$ & 0.19 & 0.19 & 0.06 & 0.34 \\
$\mathrm{CF}$ & 0.19 & 0.08 & 0.11 & 0.38 \\
\hline
\end{tabular}

Table 6. Conversion and selectivity for aniline methylation

\begin{tabular}{cccc}
\hline Catalyst & $\begin{array}{c}\text { Aniline } \\
\text { Conversion } \\
(\%)\end{array}$ & $\begin{array}{c}\text { NMA } \\
\text { Selectivity } \\
(\mathrm{wt} \%)\end{array}$ & $\begin{array}{c}\text { NNDMA } \\
\text { selectivity } \\
\text { (wt\%) }\end{array}$ \\
\hline $\mathrm{CC}$ & 33.81 & 79.23 & 16.99 \\
$\mathrm{CFC} 1$ & 35.37 & 91.53 & 8.47 \\
$\mathrm{CFC} 2$ & 59.32 & 87.68 & 12.23 \\
$\mathrm{CFC} 3$ & 50.58 & 59.11 & 40.89 \\
$\mathrm{CFC} 4$ & 41.93 & 53.24 & 43.42 \\
$\mathrm{CF}$ & 37.24 & 85.10 & 14.89 \\
\hline
\end{tabular}

clear that CFC 2 has highest surface area and acidity among the samples.

Ammonia is used to determine the acid properties. Acidity has a direct influence on aniline conversion. Weak and moderate acid sites are sufficient for $\mathrm{N}$-alkylation, where as strong acid sites are required for $\mathrm{C}$-alkylation. In $\mathrm{CuCr}_{2-\mathrm{x}} \mathrm{Fe}_{\mathrm{x}} \mathrm{O}_{4}$ series CFC 2 has more weak acid sites and hence it has more $\mathrm{N}$-alkylated product. There is a good correlation between the weak acidity obtained from ammonia TPD and aniline conversion .

\section{Conclusions}

Chromite spinel was prepared by the low temperature co-precipitation techniques produced homogeneous and very fine particles with high surface area. Powder XRD pattern shows the characteristic peaks of spinel indicating the phase formation. Ammonia TPD establishes the acidity distribution at various temperatures. Optimization of reaction parameters for aniline methylation has been carried out on CFC 2 and the selected the conditions are: temperature of $300{ }^{\circ} \mathrm{C}$, flow rate of $4 \mathrm{ml} / \mathrm{h}$ 
and aniline/methanol ratio of 1:5. A good correlation between weak acidity and aniline conversion is also observed.

\section{References}

[1] Landolt-Bronstein, Magnetic oxides and related compounds, Springer Berlin, 3 (1970).

[2] Goodenough, J.B. (1971). Metallic oxides, Progress in Solid State Chemistry. 5: 145-399.

[3] Bragg, W.H. (1915). The structure of the spinel group of crystal. Philosophical Magazine, 30: 305-315.

[4] Hill, R.J., Caig, J.R., Gibbs, G.V. (1979). Systematics of the spinel structure type. Physics and Chemistry of Minerals. 4: 317-339.

[5] Navrotsky, A., Kleppa, O.J, (1967). The thermodynamics of cation distributions in simple Spinels. Journal of Inorganic and Nuclear Chemistry. 29: 2701-2714.

[6] Dunitz, J.D., Orgel, L.E. (1957). Electronic properties of transition-metal oxides-I: Distortions from cubic symmetry. Journal of Physics and Chemistry of Solids. 3: 20-29.

[7] Rennard, R.J., Kehi, W.L. (1971). Oxidative dehydrogenation of butenes over ferrite Catalysts. Journal of Catalysis. 21: 282-293.

[8] Ghorpade, S.P.(1998). Liquid-phase FriedelCrafts alkylation using $\mathrm{CuCr}_{2-\mathrm{x}} \mathrm{Fe}_{\mathrm{x}} \mathrm{O}_{4}$ spinel catalys. Applied Catalysis A: General. 166: 135-142.

[9] Sharpe, P.K., Vickerman, J.C., Stanay, M.H. in Proceedings of the sixth International Congress on Catalysis, London, 1976.

[10] Dube, G.R., Darshane, V.S. (1991). X-ray, Electrical and catalytic studies of the system $\mathrm{CoFe}_{2} \mathrm{O}_{4}-\mathrm{Co}_{2} \mathrm{TiO}_{4}$. Bulletin of Chemical Society of Japan. 64: 2449-2453.

[11] Nayak, H., Bhatta, D. (2002). Catalytic effects of magnesium chromite spinel on the decomposition of lanthanum oxalate. Thermochimica Acta 389: 109-119.

[12] Haralambous, K.J., Loizos, Z., Spyrellius, N. (1991). Catalytic propertiesof some mixed transition-metal oxides. Material Letters. 11: 133-141.

[13] Shimokawabe, M., Furuichi, R., Ishii, T. (1977). Effect of Metal-Oxide Additives on Thermal- Decomposition of Perchlorates, Oxalates and Hydroxides. Thermochimica Acta. 20: 347-361.

[14] Said, A.A., Hassan, E.A., Abd EI.-Salaam, K.M. (1983). Electrical conductivity and thermogravimetric studies of the thermal decomposition of doped cobalt carbonate. Surface Technology. 20:123-130.
[15] Ko, A.N., Yang, C.L., Zhu, W.D., Lin, H.E. (1996). Selective N-alkylation of aniline with methanol over y-alumina. Applied Catalysis. A: General. 134: 53-66

[16] Narayanan, S., Deshpande K. (1998). Acid activation of montmorillonite : Effect on structural and catalytic properties. Studies in Surface Science and Catalysis. 113: 773-778.

[17] Elangovan, S.P., Kannan, C., Arabindoo B., Murugesan, V. (1998). Applied Catalysis A: General 174: 213-219.

[18] Chen, P.Y., Chen, M.C., Chen, H.Y., Chang, N.S., Chung, T. K., (1986). New developments in Zeolite Science and Technology. (Y. Murakami, A. Iijima, and J.W. Ward, Eds) Studies in Surface Science and Catalysis Elserier Amsterdam $28: 279$.

[19] Lian Su, B., Barthomeuf, D., (1995) Alkylation of aniline with methanol: change in selectivity with acido-basicity of faujasite catalysts. Applied Catalysis A: General 24 :73-80.

[20] Ivanova, I.I., Pomakhina, E.B., Rebrov, A.I., Hunger, M., Kolyagin, Y.G. Jens, W. (2001). Surface Species Formed during Aniline Methylation on Zeolite $\mathrm{H}-\mathrm{Y}$ Investigated by in Situ MAS NMR Spectroscopy. Journal of Catalysis. 203 : 375-381.

[21] Bautista, F.M., Campelo, J.M., Garcisa, A., Luna, J.D., Marinas, M., Romero, A.A. (1997). Heterogeneous catalysis and Fine chemicals IV, Studies in Surface Science and Catalysis, Elsevier, Amsterdam, 108: 123.

[22] Sreekumar, K., Jyothy, T., Sugunan, S. (2000). Kinetics of N-monomethylation of aniline with methanol over $\mathrm{Zn}_{1-\mathrm{x}} \mathrm{Co}_{\mathrm{x}} \mathrm{Fe}_{2} \mathrm{O}_{4}$ $(\mathrm{x}=0,0.2,0.8,1.0)$ type systems. Reaction Kinetics and Catalysis Letters.70: 161-167.

[23] Sreekumar, K., Sugunan, S. (2002). Ferrospinels based on Co and Ni prepared via a low temperature route as efficient catalysts for the selective synthesis of o-cresol and 2, 6xylenol from phenol and methanol. Journal of Molecular Catalysis A: Chemical. 185: 259262

[24] Rahna, K.S., Nisha, K., Sugunan, S. (2003). Acidity and aniline alkylation of Mixed Fe-Al Pillared Montmorillonites. Reaction Kinetics and Catalysis Letters. 79: 19-26.

[25] Nisha, K., Rahna, K.S., Sugunan, S. (2003) . Selective Alkylation of Aniline to N-methyl aniline using chromium Manganese Ferrospinels, Journal of Molecular Catalysis A: Chemical. 209: 89-96 . 